\title{
Tanker Milk Variability According to Farm Feeding Practices: Vitamins A and E, Carotenoids, Color, and Terpenoids
}

\author{
C. Agabriel, ${ }^{* 1}$ A. Cornu, $\dagger$ C. Journal, ${ }^{*}$ C. Sibra, ${ }^{*}$ P. Grolier, $\ddagger$ and B. Martin $\S$ \\ *Enita Clermont, Unité Élevage et Production des Ruminants (Unité soutenue par l'INRA), 63370 Lempdes, France \\ †INRA, UR370 Qualité des Produits Animaux, Theix, 63122 St-Genès-Champanelle, France \\ †INRA, UMR1019 Nutrition Humaine, Theix, 63122 St-Genès-Champanelle, France \\ §INRA, UR1213 Herbivores, Theix, 63122 St-Genès-Champanelle, France
}

\begin{abstract}
The aim of this work was to study the variability in the composition of bulk milk mixtures of fat-soluble compounds (vitamins A and E, carotenoids, and terpenoids) and assess the links with milk production conditions. Milk from 10 collection trips in the French department of the Haute-Loire (10 to 36 herds per trip) was sampled in the tanker twice during the winter period and 3 times during the grazing season. The collection trips differed in their altitude (440 to $1,150 \mathrm{~m}$ ) and the forage system (grass or based on corn silage). Vitamins $\mathrm{A}$ and $\mathrm{E}$, carotenoids, and terpenoids of the 50 tanker loads of milk were analyzed. Data of milk production conditions in the 204 farms made it possible to constitute indicators for the collection trip and to define 50 mean herds. The relationships between mean herd characteristics (breed, stage of lactation, and feed) and milk characteristics were investigated. The constituents of tanker loads of milk were comparable to those observed in milk produced by groups of animals receiving contrasting diets (rich in concentrate or corn silage vs. pasture). The characteristics of the milk differed according to the period; those produced at grazing were more yellow (1.02 \pm 0.4 ; mean of difference) and richer in $\beta$-carotene, lutein, vitamin $\mathrm{E}(2.0 \pm 1.2,0.23 \pm 0.12$, and $6.1 \pm 5.0 \mu \mathrm{g} / \mathrm{g}$ of fat, respectively), and sesquiterpenes $(2.7 \pm 2.5)$ than winter. The variations observed for $\beta$-carotene, lutein, and vitamin $\mathrm{E}$ were linked to the proportion of grazed grass or grass silage in the forage $(\mathrm{r}=0.66,0.69$, and 0.51 , respectively), unlike the vitamin A content. During grazing, 20 of the 32 terpenoids identified were associated with the proportion of permanent grassland available for grazing or cut. These results show that feeding is an effective way to modify the quality of dairy products, even in the case of bulk
\end{abstract}

Received March 6, 2007.

Accepted June 5, 2007.

${ }^{1}$ Corresponding author: agabriel@enitac.fr tank milk mixtures. Dairy plants could market different milks, which would contain specific compositions. Key words: tanker milk, vitamin A and E, carotenoid, terpenoid

\section{INTRODUCTION}

Terpenes are plant secondary metabolites biosynthetically derived of isoprene units. Among this vast family of molecules, monoterpenoids, sesquiterpenoids, and carotenoids pass through the animal into the milk with some minor alterations and occur in dairy products at levels highly depending on dietary supply. Only mono- and sesquiterpenes, respectively, composed of 2 and 3 isoprene units, together with their oxygen-containing derivatives, will be called terpenoids in this paper. Carotenoids, which are high molecular weight terpenes composed of 8 isoprene units, will be considered separately.

Carotenoids are important in human health and nutrition because of their provitamin A function and antioxidant properties. In spite of their low percentage in milk, carotenoids ( $\beta$-carotene and lutein) are involved in the sensorial properties of dairy products via their colorant and antioxidant properties. They vary under the effect of several factors linked to the animals (breed, parity, physiological stage, level of intake) and more so under the effect of their feed (amount of dietary carotene; Nozière et al., 2006). Specific effects of the nature and preservation mode of forage have been quantified in the content of individual milks of $\beta$-carotene and vitamins A and E (Martin et al., 2004). In the case of milk and cheese from cows, diets rich in concentrate or corn silage, when compared with pasture rich in carotenoids and antioxidants, resulted in lower content in carotenoids and vitamin $\mathrm{E}$ (Martin et al., 2004). Contrasting results obtained under experimental conditions were confirmed at the herd level in work conducted with producers of farmhouse cheese (Lucas et al., 2006a).

Dairy mono- and sesquiterpenoids attracted interest both for their possible effect on cheese sensory proper- 
Table 1. General characteristics of the zones of the department of the Haute-Loire (Massif Central, France)

\begin{tabular}{|c|c|c|c|}
\hline \multirow[b]{2}{*}{ Item } & \multicolumn{3}{|c|}{ Zone $^{1}$} \\
\hline & $\mathrm{Z} 1$ & $\mathrm{Z} 2$ & $\mathrm{Z3}$ \\
\hline Collection trips (n) & 4 & 4 & 2 \\
\hline Farms collected/trip (n) & 12 & 31 & 10 \\
\hline Dairy quota $\left(10^{3} \mathrm{~L} /\right.$ farm $)$ & 146 & 137 & 86 \\
\hline Agricultural area (ha/farm) & 58 & 65 & 56 \\
\hline Altitude of the farmsteads (m) & 622 & 1,023 & 1,129 \\
\hline \multicolumn{4}{|l|}{$\begin{array}{l}\text { Breed of dairy cows } \\
\text { (\% milk collected) }\end{array}$} \\
\hline Montbéliarde & 50 & 80 & 97 \\
\hline Holstein & 47 & 18 & 2 \\
\hline
\end{tabular}

${ }^{1}$ The zones (Z1, Z2, and Z3) will be synthesized by their dominant forage system in further tables.

ties (Martin et al., 2005) and as potential milk and cheese markers of the presence of diversified forage in the diet of dairy cows (Viallon et al., 1999; Bendall, 2001). Indeed, they abound in certain aromatic species, dicotyledons in particular (Mariaca et al., 1997; Cornu et al., 2001), and terpene concentration in forage is mainly governed by its botanical composition and its stage of maturity (Tornambé et al., 2006). These molecules pass rapidly into the milk (Viallon et al., 2000) with some minor alterations and are found in milk and cheese in a much greater quantity when animals are fed dicotyledon-rich natural grass forage than when they are fed concentrate-based rations (Moio et al., 1996) or monospecific forage (Viallon et al., 1999; Bugaud et al., 2001).

To our knowledge, these milk compounds, which come directly from the feed consumed by the animals and whose variability is well known, have rarely been studied in bulk milk mixtures from several farms (Smit et al., 2000; Hulshof et al., 2006). The objectives of this study were to work with bulk tank milk to quantify the variability of the milk composition and assess the possible links with the milk production conditions, feeding in particular.

\section{MATERIALS AND METHODS}

The study was conducted in 204 farms situated in 3 zones (Z1, Z2, and Z3) of the department of the HauteLoire (Massif Central, France) distinguished by their forage system (grassland or based on corn silage) and altitude (440 to $1,150 \mathrm{~m}$; Table 1 ). A total of 10 collection trips, each including from 10 to 36 farms and from 220 to nearly 1,000 cows milked, were studied. The average agricultural area of the farms was close to 60 ha in the
3 zones. The herds were composed of $27 \pm 1$ (mean \pm SE) cows for a milk quota of $130,000 \mathrm{~L}$, which was lower in Z3 than in the other zones. The average altitude of the collection trips in the 3 zones ranged from 593 to $1,124 \mathrm{~m}$. The Montbéliarde breed in Z2 and Z3 produced more than $80 \%$ of the milk, whereas Montbéliarde and Holstein breeds were equivalent in Z1.

Milk from the 10 collection trips was sampled 5 times during 2002 during key periods in animal feeding: twice during the overwintering period with diets based on preserved forage (February and March), and 3 times during the grazing period: return to pasture with abundant young grass in May, summer drought in July, and regrowth at the end of September.

\section{Milk Production Data Collection}

Four surveys were carried out with each producer by technicians visiting these farms on a regular basis. In the first general survey, questions were asked about 1) farm characteristics (area, altitude, stable and milking equipment, milk quota), 2) herd characteristics (dairy cow number, breed), 3) forage management (forage characteristics, forage harvesting and conservation, cutting and grazing periods, cropping pattern during 2001), and 4) feeding the herd during winter (types of feed). During grazing, 3 complementary surveys were carried out during the week of each milk collection to specify herd characteristics (cow numbers) and herd feeding (pasture, preserved forage, concentrate). Special attention was paid to the forage (corn, grass), the grassland (permanent or temporary grassland), the preservation mode (pasture, hay, silage, and wrapped forage), and the growth cycle of the preserved grass (first or higher cutting) and the estimated respective 
levels of each of these feeds. Calving distribution information was collected from the administrative services in charge of animal identification to determine the average physiological stage at each milk collection period. The dairies supplied the quantity of milk delivered by each of the farms at each collection.

\section{Sample Collection of Tanker Milk and Milk Analyses}

For each of the 50 collections (10 collection trips $\times 5$ periods), the milk from 4 (exceptionally 6 ) milkings, stored in the farm bulk tanks, was collected in tankers containing from 4,082 to $32,998 \mathrm{~L}$. One liter of milk was sampled from each tanker, kept at $4^{\circ} \mathrm{C}$ without preserving agent, and taken to the laboratory.

Fat, protein, and lactose (infrared spectrophotometry, Milkoscan 4000, Foss Electric, Hillerød, Denmark); SCC (Automatic Counter Fossomatic 5000, Foss Electric); spores of butyric acid bacteria (CNERNA, 1986); and total flora at $30^{\circ} \mathrm{C}$ (AFNOR, 2003) were assessed in the fresh milk. Color measured by reflectance was determined from 400 to $700 \mathrm{~nm}$ (10-nm steps) on fresh milk using a spectrocolorimeter (Minolta CM 2002, Minolta, Carrières sur Seine, France), and the traceability index was calculated as the upper area of the reflectance spectra from 450 to $530 \mathrm{~nm}$ (Nozière et al., 2006).

The other analyses were performed on frozen milk at $-80^{\circ} \mathrm{C}$ for vitamins $\mathrm{A}$ and $\mathrm{E}$ and at $-20^{\circ} \mathrm{C}$ for carotenoids and terpenoids. Retinol (vitamin A), $\alpha$-tocopherol (vitamin E), $\beta$-carotene, and xanthophylls were analyzed as described by Lucas et al. (2006b). Milk lipid was obtained by centrifugation and analyzed for terpenoid by dynamic headspace-GC-MS (Tornambé et al., 2006) on 1 sampling period in winter and on 3 sampling periods during the grazing season. Terpenoids for semiquantification were detected in the selected ion mode by monitoring their characteristic ions at $\mathrm{m} / \mathrm{z}=93,136$, 161, and 204 (Fernandez et al., 2003).

\section{Data Analysis}

Milk Production Conditions in the Collection Rounds. To link the characteristics of the milk sampled from a tanker containing milk from the group of herds in the collection trip (10 to 36 ) and the milk production conditions recorded at the level of each farm, 50 mean herds corresponding to the 50 milk samples were created. Each mean herd characteristic was defined as the mean of the characteristics of the herds of the collection trip weighted by the volume of milk collected in each herd ( 0.1 to $27.6 \%$ of the tanker milk). The basic data relative to these mean herds made it possible to describe the forage (permanent or temporary grassland, whole plant corn), its preservation mode (grazed grass, reaped or wrapped hay, grass or corn silage), the altitude where it was consumed, the quantity of concentrate distributed, the breed (Montbéliarde, Holstein), and the physiological stage of the animals.

We described the ration by proportions of feeds in the forage ration calculated from the quantities the farmers declared they distributed or the estimated intake of standing grass at grazing (Agabriel et al., 2005).

Characterization of Tanker Milks and Production Conditions. The SAS software (Version 6.12, SAS Institute Inc., Cary, NC) was used for data analyses. Data were processed using the repeated measures procedure, introducing zone into the model (linked with the milk production conditions as described below), period, and the interaction. Because the characteristics of the milk were correlated at different periods, period was considered a repeated factor. The relations between the variables were characterized by the correlation coefficients (PROC CORR).

\section{RESULTS}

\section{Characteristics of the Production Conditions}

Milk production conditions in Z1, Z2, and Z3 corresponded to the gradual shift from the feeding systems based on the use of plain corn silage, with a large proportion of milk produced by Holsteins (Z1), to mountain feeding systems based on permanent grasslands and associated with an increasing proportion of Montbéliarde cows (Z3). The calvings were globally spread over the year so that the lactation stage in the 3 zones at different periods ranged from 4.9 to 6.3 mo (data not shown).

The forage of the 50 mean herds varied both in the way the forage was preserved ( 5 to $83 \%$ hay, 0 to $52 \%$ wrapped forage, 0 to $45 \%$ grass silage, 0 to $70 \%$ corn silage, and 0 to $88 \%$ grazed grass) and in the forage itself ( 15 to $100 \%$ permanent grassland, 0 to $73 \%$ temporary grassland, and 0 to $70 \%$ whole plant corn). The quantities of concentrates varied from 1.8 to $5.5 \mathrm{~kg} / \mathrm{d}$ per cow. The milk production conditions were linked with the zones. Nevertheless, those links varied according to the period as shown by the significant zone $\times$ period interactions (Table 2 ) observed for the majority of the variables describing the milk production conditions. Diets in Z1 included corn silage ( $49 \pm 5 \%$; mean $\pm \mathrm{SE}$ ) of the forage during the winter feeding period (February, March) and $22 \pm 4 \%$ during the grazing period (May, July, September), whereas they were exclusively based on grass forage in Z2 and Z3 (99 $\pm 1 \%$, Figure 1). The grass came from permanent grasslands in Z3 and from both permanent and temporary grasslands in Z1 and Z2. The proportion of permanent grass- 
Table 2. Characteristics of production conditions of the zones of the department of the Haute-Loire (Massif Central, France) during different times of the year

\begin{tabular}{|c|c|c|c|c|c|c|c|c|c|c|c|c|}
\hline \multirow[b]{3}{*}{ Item } & \multirow{2}{*}{\multicolumn{3}{|c|}{ Zone $^{1}$}} & \multirow{2}{*}{\multicolumn{5}{|c|}{ Period }} & \multirow[b]{3}{*}{ SE } & \multicolumn{3}{|c|}{$P$} \\
\hline & & & & & & & & & & \multirow[b]{2}{*}{ Zone } & \multirow[b]{2}{*}{ Period } & \multirow{2}{*}{$\begin{array}{c}\text { Zone } \\
\times \text { period }\end{array}$} \\
\hline & $\mathrm{Z1}$ & $\mathrm{Z} 2$ & $\mathrm{Z3}$ & Feb. & Mar. & May & Jul. & Sep. & & & & \\
\hline Physiological stage (mo) & 5.7 & 5.4 & 5.5 & 5.3 & 5.3 & 5.6 & 5.7 & 5.6 & 0.2 & $\mathrm{NS}^{2}$ & NS & $* * *$ \\
\hline \multicolumn{13}{|l|}{ Nature of forage (\% of DM) } \\
\hline Permanent grassland & $35^{\mathrm{a}}$ & $54^{\mathrm{b}}$ & $96^{\mathrm{c}}$ & $52^{\mathrm{a}}$ & $53^{\mathrm{a}}$ & $75^{\mathrm{c}}$ & $66^{\mathrm{b}}$ & $65^{\mathrm{b}}$ & 6 & **** & $* * *$ & $*$ \\
\hline Temporary grassland & $32^{\mathrm{b}}$ & $44^{\mathrm{c}}$ & $3^{\mathrm{a}}$ & $31^{\mathrm{b}}$ & $31^{\mathrm{b}}$ & $18^{\mathrm{a}}$ & $28^{\mathrm{b}}$ & $25^{\mathrm{ab}}$ & 6 & $* * *$ & $* * *$ & $* *$ \\
\hline Grass & 35 & 42 & 46 & $0^{\mathrm{a}}$ & $0^{\mathrm{a}}$ & $73^{\mathrm{c}}$ & $71^{\mathrm{c}}$ & $62^{\mathrm{b}}$ & 5 & NS & $* * *$ & NS \\
\hline Hay & $14^{\mathrm{a}}$ & $30^{\mathrm{b}}$ & $40^{\mathrm{b}}$ & $40^{\mathrm{b}}$ & $41^{\mathrm{b}}$ & $17^{\mathrm{a}}$ & $18^{\mathrm{a}}$ & $22^{\mathrm{a}}$ & 5 & $* *$ & $* * *$ & *** \\
\hline Wrapped & 2 & 13 & 15 & $21^{\mathrm{b}}$ & $22^{\mathrm{b}}$ & $2^{\mathrm{a}}$ & $2^{\mathrm{a}}$ & $3^{\mathrm{a}}$ & 4 & NS & $* * *$ & $* * *$ \\
\hline Grass silage & $16^{\mathrm{b}}$ & $14^{\mathrm{b}}$ & $0^{\mathrm{a}}$ & $21^{\mathrm{b}}$ & $21^{\mathrm{b}}$ & $0^{\mathrm{a}}$ & $3^{\mathrm{a}}$ & $4^{\mathrm{a}}$ & 4 & $* *$ & $* * *$ & $* *$ \\
\hline Corn silage & $33^{\mathrm{b}}$ & $1^{\mathrm{a}}$ & $1^{\mathrm{a}}$ & $18^{\mathrm{b}}$ & $17^{\mathrm{b}}$ & $8^{\mathrm{a}}$ & $6^{\mathrm{a}}$ & $10^{\mathrm{a}}$ & 5 & $* *$ & $* * *$ & $* * *$ \\
\hline Concentrates (kg/cow per d) & $3.8^{\mathrm{b}}$ & $4.1^{\mathrm{b}}$ & $2.8^{\mathrm{a}}$ & $4.2^{\mathrm{c}}$ & $4.2^{\mathrm{c}}$ & $3.2^{\mathrm{ab}}$ & $2.9^{\mathrm{a}}$ & $3.4^{\mathrm{b}}$ & 0.3 & $*$ & $* * *$ & NS \\
\hline
\end{tabular}

land was greater at grazing than during the winter period.

In $\mathrm{Z} 1$, the forage included 49,31 , and $18 \%$ of corn silage, grass silage, and hay during the winter feeding period, respectively (Figure 1), and was supplemented with $4.4 \mathrm{~kg}$ of concentrate, whereas during the grazing period, the forage included 59, 22, and $12 \%$ of grazed grass, corn silage, and hay, respectively, and $3.5 \mathrm{~kg}$ of concentrate. In Z2, the forage included 39, 33, and $26 \%$ of hay, grass silage, and wrapped fodder during the winter feeding period, respectively, and was supplemented with $5.0 \mathrm{~kg}$ of concentrate, whereas during the grazing period, the forage included 71 and $23 \%$ of grazed grass and hay, respectively, and $3.5 \mathrm{~kg}$ of concentrate. In Z3, both during the winter feeding period and the grazing period, the forage was composed of permanent grassland with fewer concentrates than in $\mathrm{Z} 1$ and Z2 (respectively, 3.3 and $2.6 \mathrm{~kg}$ in winter and summer). The forage was composed of hay (65\%) and wrapped fodder $(35 \%)$ during the winter feeding period and grazed grass (77\%) and hay (23\%) during the grazing period.

\section{Milk from the Collection Trips}

The lactose and protein contents of the 50 samples (data not shown) were not variable $(49.7 \pm 0.1$ and 32.4 $\pm 0.1 \mathrm{~g} / \mathrm{L}$, respectively, with a $\mathrm{CV}<3 \%$ ) and differed by period $(P<0.001$; Table 3$)$. The fat content, the total flora, and butyric spore contents varied $(42.6 \pm 1 \mathrm{~g} / \mathrm{L}$, $2.1 \pm 0.1 \mathrm{cfu} / \mathrm{mL}-\log 10$, and $2.93 \pm 0.09$ spores/L-log 10 , respectively; $\mathrm{CV}$ of 10,28 , and $21 \%$, respectively). The protein content was higher in $\mathrm{Z} 1(32.6 \pm 0.2 \mathrm{~g} / \mathrm{kg} ; P<$ 0.05 ) than the other zones, but the other components did not vary significantly by zone (Table 3 ).

Vitamin $A$ and $E, \beta$-Carotene, and Lutein. The $\beta$-carotene, which represented $4.3 \pm 0.2 \mu \mathrm{g} / \mathrm{g}$ of fat, was the principal compound of the family of carotenoids in milk. The lutein contents $(0.43 \pm 0.02 \mu \mathrm{g} / \mathrm{g}$ of fat) were about 10 times lower than $\beta$-carotene. Vitamin $\mathrm{A}$ and E contents were $7.2 \pm 0.3$ and $17.5 \pm 0.8 \mu \mathrm{g} / \mathrm{g}$ of fat, respectively. The variability of these 4 fat-soluble compounds was comparable (CV 33 and 38\%).

The vitamin A content of the milk did not vary significantly either with the zone or with the period $(P>$ 0.05 ; Table 3$)$. No differences $(P>0.05)$ were observed by zone for vitamin $\mathrm{E}, \beta$-carotene, and lutein. On the other hand, their contents in milk were higher $(P<$ 0.01 ) during the grazing period (May, July, and September) than those measured during the winter feeding period (February and March; Table 3). During the grazing period, there was no clear connection between these compounds and the variables describing the production conditions (concentrate, nature of forage, and method of forage conservation including the proportion of grazed grass) except for lutein, which was linked to the proportion of permanent grassland $(\mathrm{r}=0.44 ; P<0.05)$ and that of corn $(\mathrm{r}=-0.52 ; P<0.01)$. During the winter period, the $\beta$-carotene content of the milk was correlated to the amount of hay in the ration $(\mathrm{r}=-0.50 ; P$ $<0.05$ ). Overall, lutein and $\beta$-carotene contents were associated with the proportion of wet forage, grass + 

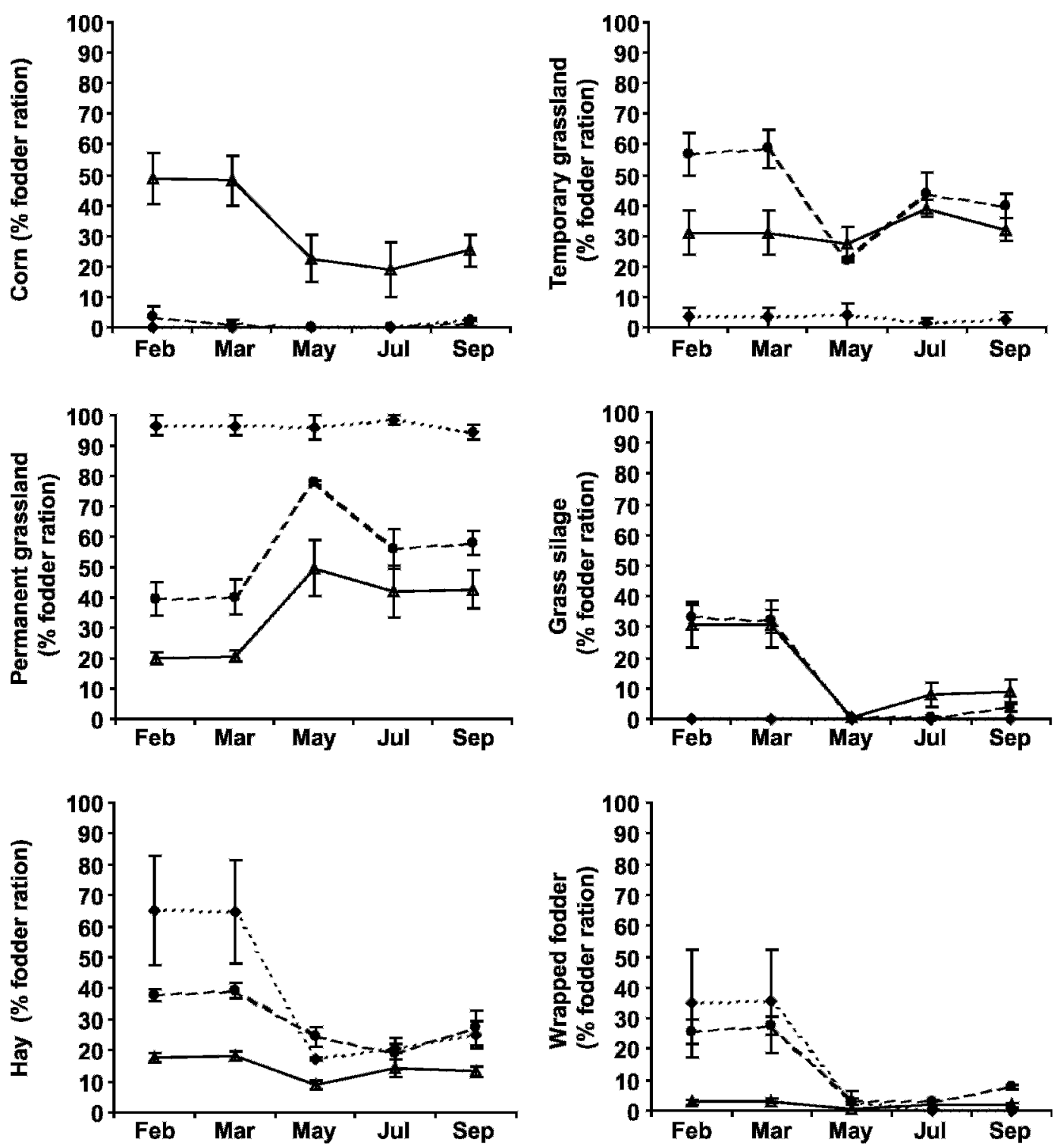

Figure 1. Forage evolution according to the period and the zone from farms of 3 zones of the department of the Haute-Loire (Massif Central, France) during different times of the year. Z1: $\triangle, \ldots$; Z2: $\bullet,--$; Z3: $\bullet, \ldots$ (mean \pm SE). Dominant forage system of the farms based on corn silage and temporary grassland for Z1; permanent grassland and temporary grassland, hay made, wrapped, or as silage for Z2; and permanent grassland, hay made or wrapped for Z3.

grass silage, in the ration (Figure $2 ; \mathrm{r}=0.69$ and $\mathrm{r}=$ $0.66 ; P<0.0001$, respectively). Additionally, there was a positive link between vitamin $\mathrm{E}$ and the proportion of wet forage ( $\mathrm{r}=0.51 ; P<0.001)$, whereas there was no link for vitamin A $(P>0.05)$.

Color Measurements. The brightness $(82.1 \pm 0.1)$ and the red $(-1.12 \pm 0.03)$, yellow $(8.57 \pm 0.09)$, and color $(614 \pm 7)$ indices differed by period $(P<0.001$; Table 3$)$. The $\beta$-carotene content of milk explained 39 and $43 \%$, respectively, of the variations of these 2 indices (Figure 3).
Milk sampled during the grazing period (May, July, and September) had higher yellow and color indices than that obtained during February and March. The red index decreased gradually $(P<0.001)$ from $\mathrm{Z} 1$ to Z3. There were no observed differences for other color indicators by zone. The proportions of wet forage explained 56 and $60 \%$, respectively, of the variability of the yellow and color indices (Figure 2). During the winter period, the proportion of forage based on fermented grass explained 34 and $52 \%$ of the variation of the yellow and color indices. There were no correlations be- 
Table 3. Description of physicochemical and microbiological characteristics, vitamins, carotenoids, and color in bulk milk samples from farms of 3 zones of the department of the Haute-Loire (Massif Central, France) during different times of the year

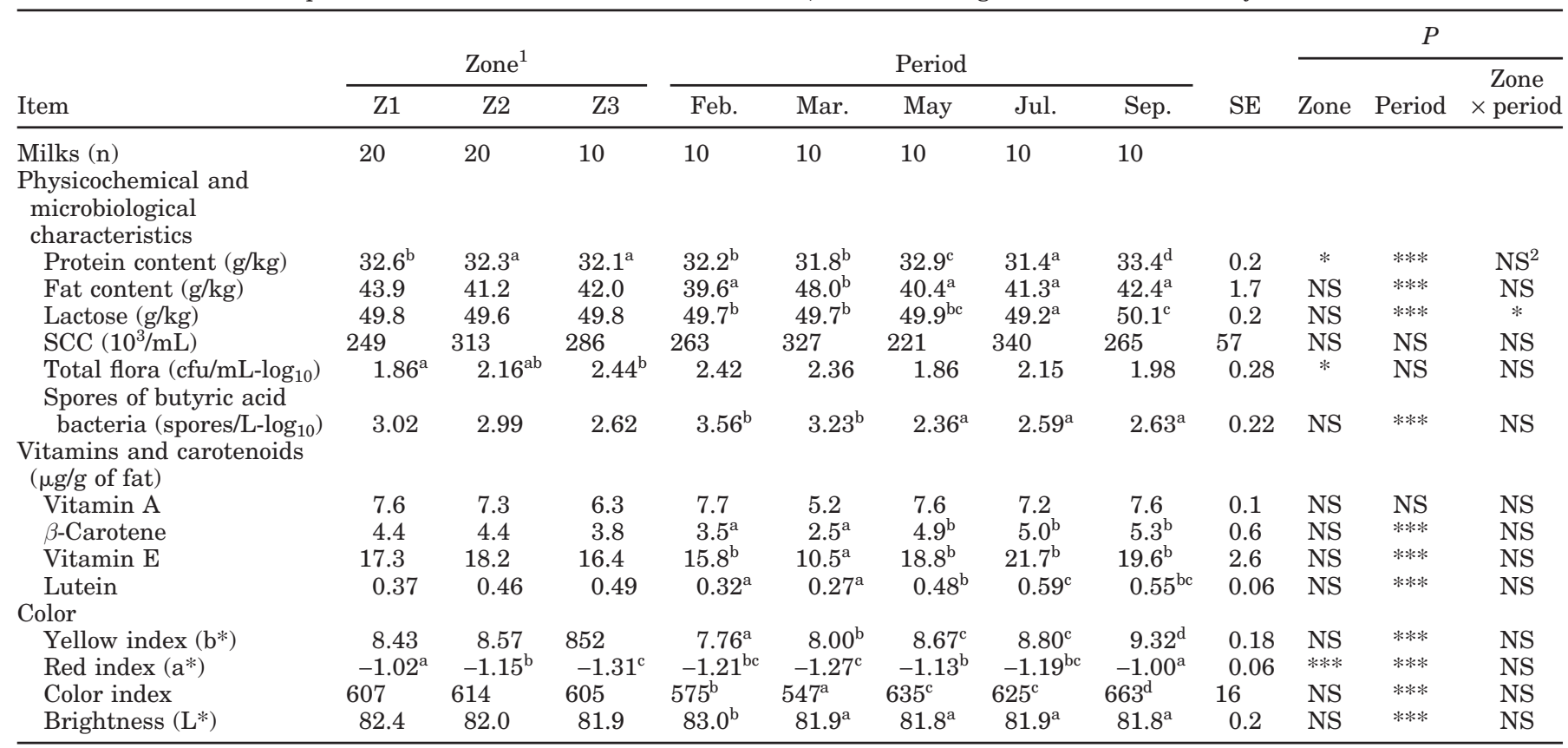

${ }^{\mathrm{a}-\mathrm{d}}$ Means within a row with different superscripts differ $(P<0.05)$.

${ }^{1}$ The zones are mainly characterized by the dominant forage system of the farms based on corn silage and temporary grassland for Z1; permanent grassland and temporary grassland, hay made, wrapped, or as silage for Z2; and permanent grassland, hay made or wrapped for Z3.

${ }^{2} P>0.05$.

$* P<0.05$; *** $P<0.001$.

tween the color of the milk and the variables describing the milk production conditions during the summer period.

Terpenoids. Monoterpenoids desorbing from milk fat were 2.5 times greater than sesquiterpenoids (10.4 \pm 0.9 and $4.2 \pm 0.4$, respectively). Their variability was high and similar (CV $=63$ and $65 \%$, respectively). Sesquiterpenoids were higher in the milks from the grazing period (May, July, and September) than from the winter period (February; $P<0.001$; Table 4 ). The overall contents in monoterpenoids did not vary significantly according to the zone, whereas sesquiterpenoids increased from Z1 to Z3 $(P<0.001)$. During the grazing period, milk sesquiterpenoids were related to the proportion of grazed grass in the forage diet $(\mathrm{r}=0.56 ; P<$ 0.01 ), to the proportion of forage based on permanent grassland $(\mathrm{r}=0.66 ; P<0.0001)$, to the proportion of $\operatorname{corn}(\mathrm{r}=-0.61 ; P<0.001)$, and to the quantity of concentrate fed $(\mathrm{r}=-0.55 ; P<0.01)$. During the winter period, neither the mono- nor the sesquiterpenoids were linked to the variables describing the feeding of the mean herds.

In all, 46 terpenoids were found in the volatile fraction of the milk fat, almost equally distributed among mono- and sesquiterpenoids. The main terpenoids were $\alpha$-pinene, $\beta$-pinene, limonene, p-mentha-1(7)8-diene, sabinene, $\beta$-caryophyllene, and $\alpha$-copaene. Milk terpenoids had very high $\mathrm{CV}$, ranging from 33 to $156 \%$.

Among the 24 monoterpenoids, 10 [ $\alpha$-thujene, $\alpha$-pinene, m-menth-6-ene (R)-(+), sabinene, $\beta$-pinene, $\alpha$ phellandrene, $\gamma$-terpinene, $\alpha$-terpinolene, citronellyl acetate, as well as an unidentified terpene (retention index $=935)$ ] were the lowest in milk from the winter feeding period (Table 4). Similarly, among the 22 sesquiterpenoids, 13 (cubebene, $\alpha$-copaene, $\beta$-bourbonene, $\beta$-elemene, iso-longifolene, $\beta$-caryophyllene, $\alpha$-humulene, germacrene- $\mathrm{D}, \gamma$-himalachene, $\gamma$-cadinene, and 3 unidentified, retention index $=1,428,1,464$, and 1,500 ), were the lowest in milk from the winter feeding period. In contrast, $\beta$-copaene, was significantly higher $(P<$ 0.01 ) during this period. During the grazing period, the desorbed terpenes were the highest in May and July for 3 and 8 compounds, respectively. In addition, 2, 1, and 5 compounds had their lowest values in May, July, and September, respectively.

Six mono- and 9 sesquiterpenoids were significantly higher in Z3 than in Z1, Z2 being intermediate and not significantly different from Z1 for 6 mono- and 4 sesquiterpenoids (Table 4). A significant interaction between period and zone was observed for 16 compounds. 

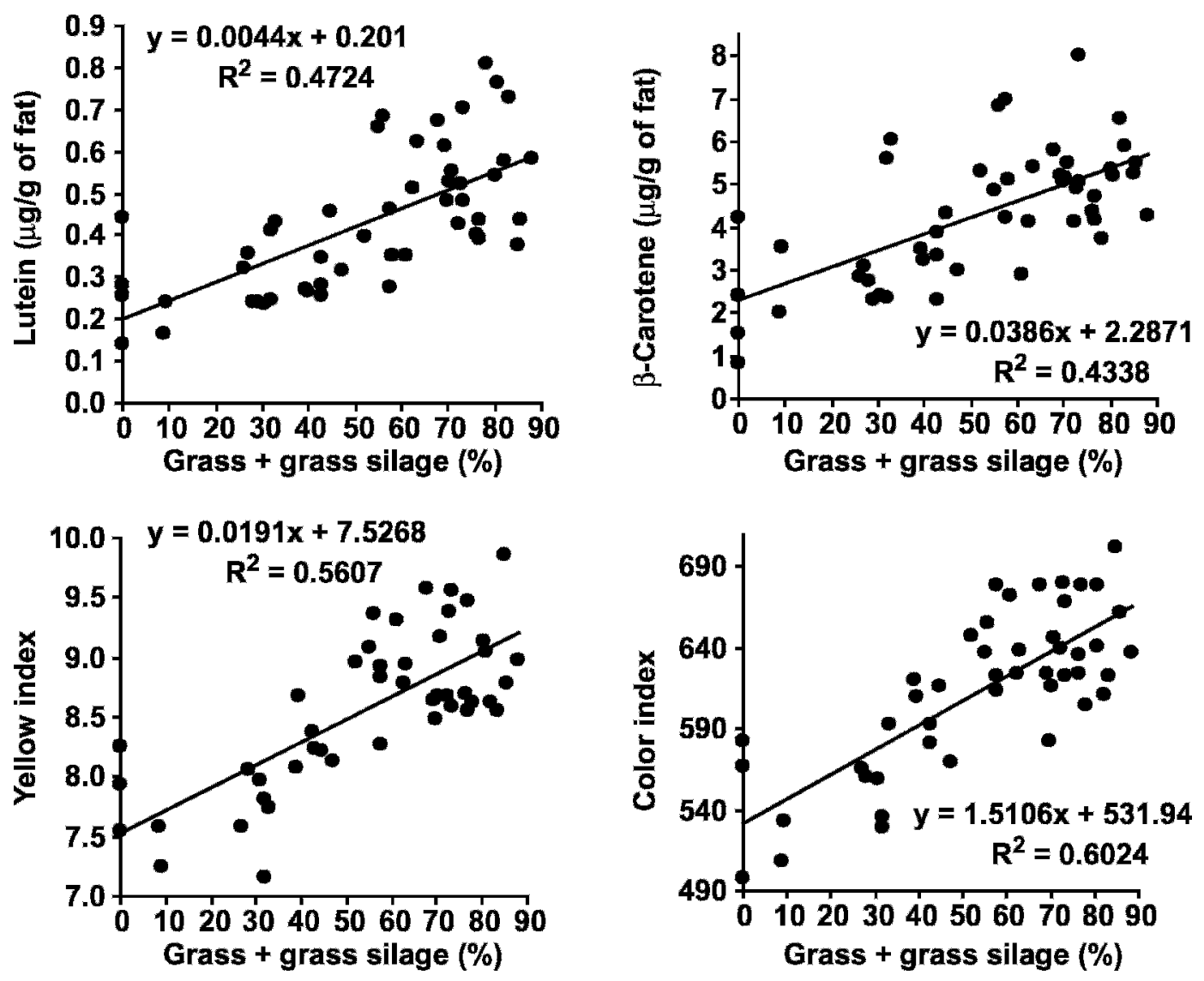

Figure 2. Relationships between the proportion of grass-based wet forage in the diet and milk carotenoids and color in bulk milk samples from farms of 3 zones of the department of the Haute-Loire (Massif Central, France) during different times of the year.
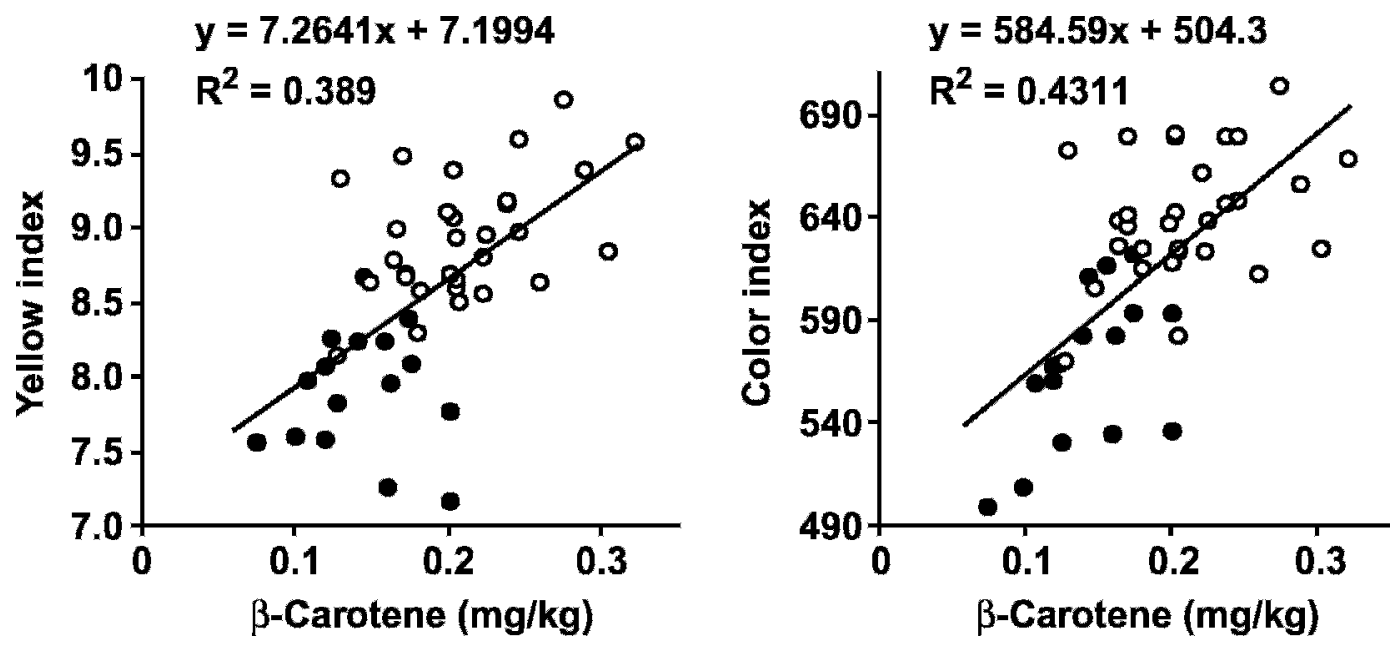

Figure 3. Relationships between milk color and its carotenoid content in bulk milk samples from farms of 3 zones of the department of the Haute-Loire (Massif Central, France) during different times of the year. Wintering: $\bullet$; grazing: $\bigcirc$; tendency for year: $\longrightarrow$. 
Table 4. Description of terpenoids $\left(10^{6} \mathrm{AAU}^{1}\right)$ found in bulk milk samples from farms of 3 zones of the department of the Haute-Loire (Massif Central, France) during different times of the year

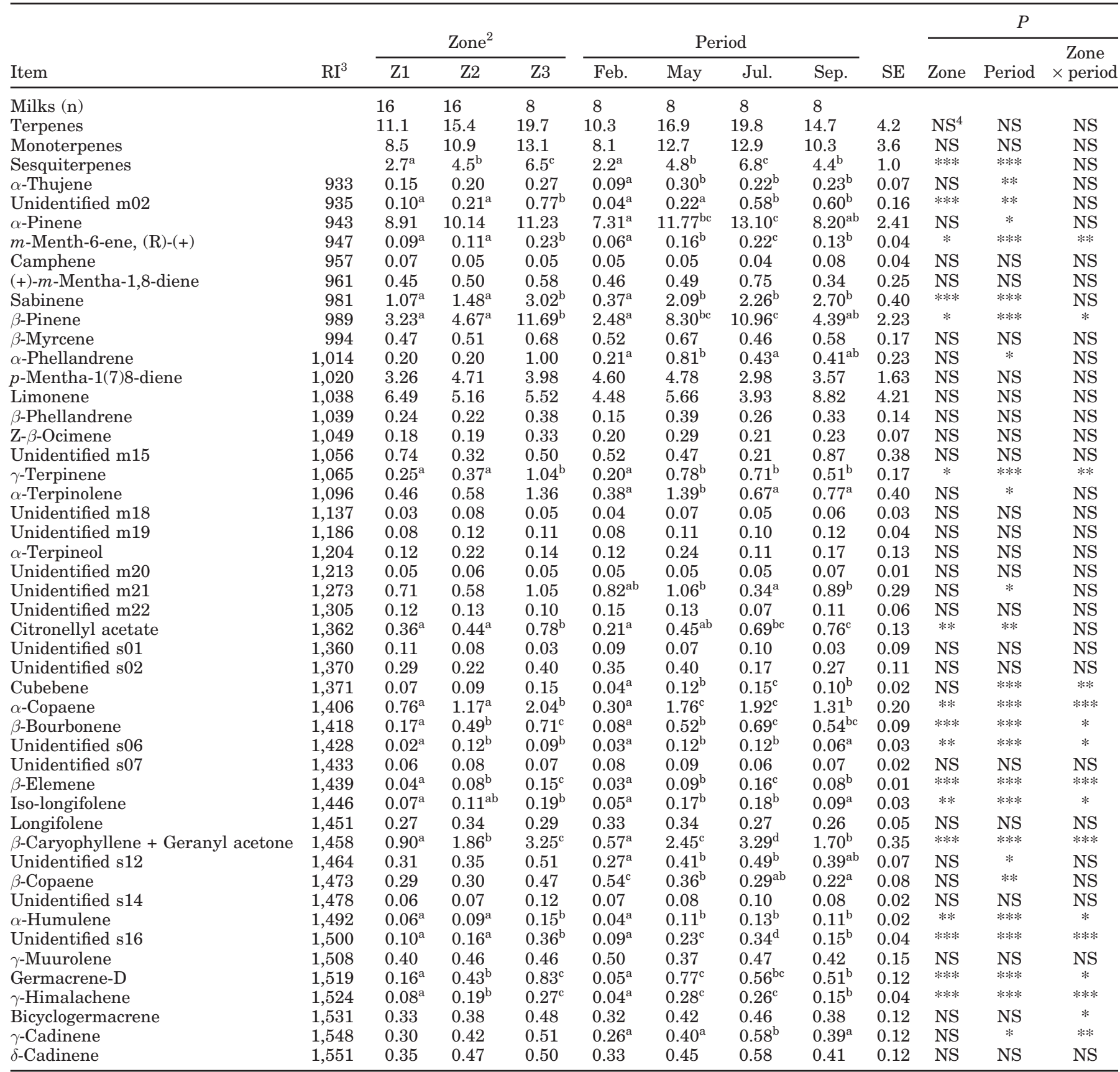

${ }^{\mathrm{a}-\mathrm{d}}$ Means within a row with different superscripts $\operatorname{differ}(P<0.05)$

${ }^{1} \mathrm{AAU}=$ arbitrary area unit.

${ }^{2}$ The zones are mainly characterized by the dominant forage system of the farms based on corn silage and temporary grassland for Z1; permanent grassland and temporary grassland, hay made, wrapped, or as silage for Z2; and permanent grassland, hay made or wrapped for Z3.

${ }^{3} \mathrm{RI}=$ retention indices.

${ }^{4} P>0.05$.

$* P<0.05 ; * * P<0.01 ; * * * P<0.001$. 

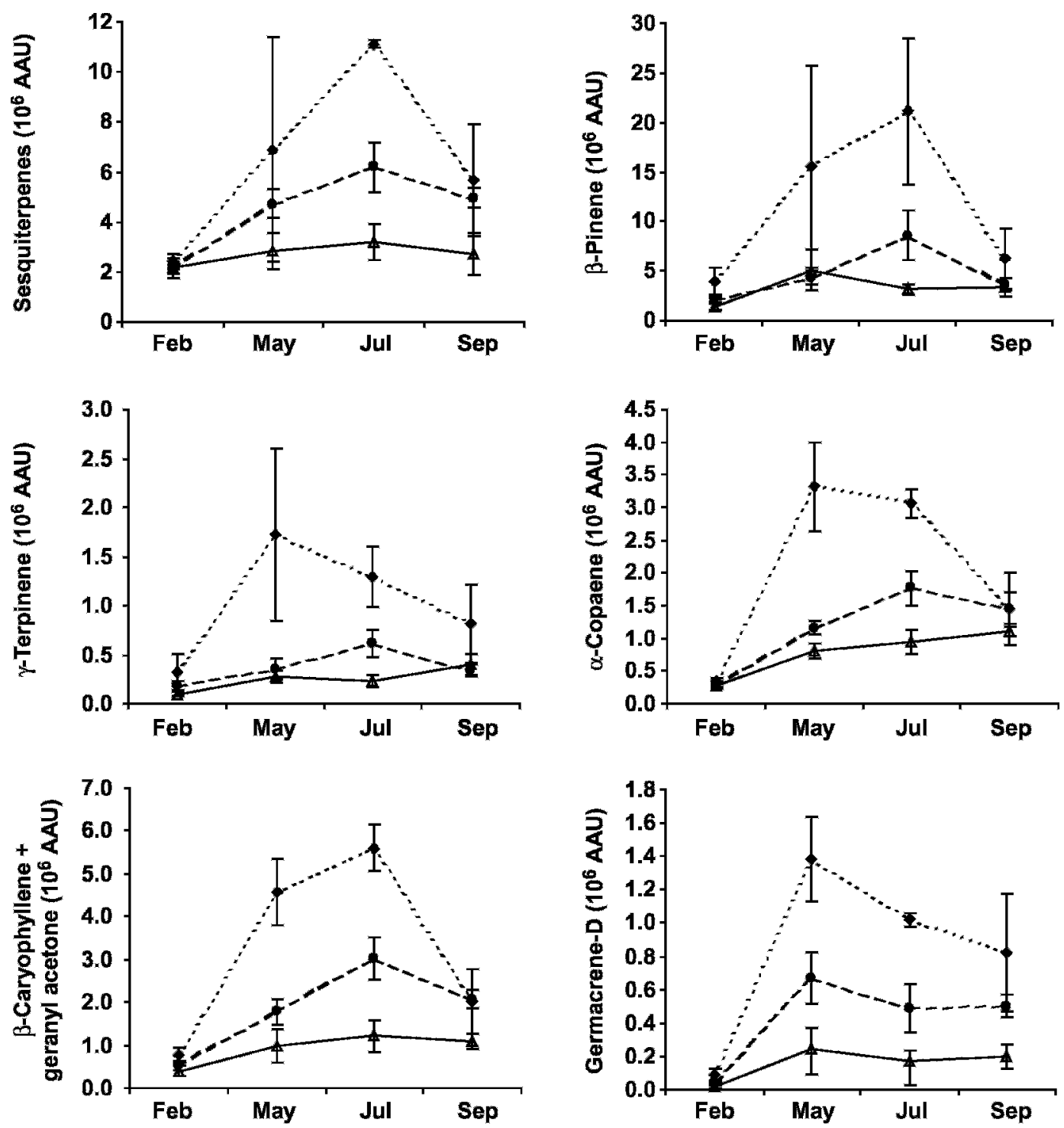

Figure 4. Terpenes evolution by period and zone (AAU = arbitrary area unit) in bulk milk samples from farms of 3 zones of the department of the Haute-Loire (Massif Central, France) during different times of the year. Z1: $\triangle$, —; Z2: ๑, - -; Z3: $\bullet, \ldots$ (mean \pm SE). Dominant forage system of the farms based on corn silage and temporary grassland for Z1; permanent grassland and temporary grassland, hay made, wrapped, or as silage for Z2; and permanent grassland, hay made or wrapped for Z3.

The most important are represented on Figure 4. These interactions generally reveal a higher influence of the period for Z3 than Z2 than Z1. The differences by zone are none in winter but higher in summer, especially in July.

Terpene contents were correlated with the herd characteristics and their feed. During the grazing period, 14,11 , and 12 identified terpenoids, respectively, were negatively correlated with the proportion of corn, temporary grassland, and quantity of concentrate in the ration, and 17, 13, and 20 identified terpenoids were correlated positively with the proportion of milk pro- duced by cows of the Montbéliarde breed and the proportion of grazed grass and grass from permanent grassland in the ration (Table 5). For the 6 compounds linked to the proportion of permanent grassland at each of the 2 seasons (as shown for 3 in Figure 5), the regression slope is from 5 to 20 times steeper during the grazing period compared with the winter feeding period.

\section{DISCUSSION}

\section{Carotenes and Vitamins}

The vitamin A contents were 1.5 times higher than those of Nozière et al. (2006). The variability of the 
Table 5. Correlations between milk terpenoids (identified) found during the grazing period in bulk milk samples from farms of 3 zones of the department of the Haute-Loire (Massif Central, France) and their production conditions $(P<0.01)$

\begin{tabular}{|c|c|c|c|c|c|c|c|}
\hline Item & Montbéliarde & Holstein & Grass & Corn & $\begin{array}{l}\text { Permanent } \\
\text { grassland }\end{array}$ & $\begin{array}{l}\text { Temporary } \\
\text { grassland }\end{array}$ & Concentrate \\
\hline$\alpha$-Thujene & & -0.48 & & & & & \\
\hline$m$-Menth-6-ene, $(\mathrm{R})-(+)$ & 0.50 & -0.48 & & & 0.52 & -0.51 & -0.58 \\
\hline Sabinene & 0.54 & -0.55 & & & 0.64 & -0.56 & \\
\hline$\beta$-Pinene & 0.49 & -0.48 & 0.50 & & 0.55 & -0.47 & -0.62 \\
\hline $\begin{array}{l}\alpha \text {-Phellandrene } \\
\beta \text {-Phellandrene }\end{array}$ & & & & & 0.51 & -0.55 & \\
\hline $\begin{array}{l}\text { j-Phellandrene } \\
\gamma \text {-Terpinene }\end{array}$ & 0.53 & -0.51 & & & 0.59 & -0.56 & -0.52 \\
\hline Citronellyl acetate & 0.53 & -0.54 & 0.49 & -0.48 & 0.61 & & -0.48 \\
\hline Cubebene & 0.58 & -0.59 & 0.61 & -0.53 & 0.62 & & -0.64 \\
\hline$\alpha$-Copaene & 0.73 & -0.73 & 0.54 & -0.49 & 0.64 & -0.50 & -0.58 \\
\hline$\beta$-Bourbonene & 0.78 & -0.80 & 0.50 & -0.66 & 0.70 & & -0.50 \\
\hline$\beta$-Elemene & 0.65 & -0.66 & 0.49 & -0.54 & 0.67 & -0.49 & -0.63 \\
\hline Iso-longifolene & 0.59 & -0.60 & 0.51 & -0.48 & 0.68 & -0.55 & -0.63 \\
\hline$\beta$-Caryophyllene & 0.68 & -0.70 & 0.57 & -0.61 & 0.70 & & -0.62 \\
\hline$\beta$-Copaene & & & 0.57 & & 0.53 & -0.50 & \\
\hline$\alpha$-Humulene & 0.63 & -0.64 & & -0.50 & 0.66 & -0.52 & -0.54 \\
\hline$\gamma$-Muurolene & & -0.49 & & -0.58 & 0.50 & & \\
\hline Germacrene-D & 0.73 & -0.74 & 0.53 & -0.60 & 0.82 & -0.65 & -0.53 \\
\hline$\gamma$-Himalachene & 0.61 & -0.63 & 0.55 & -0.59 & 0.59 & & \\
\hline Bicyclogermacrene & 0.49 & -0.54 & & -0.57 & 0.64 & & \\
\hline$\gamma$-Cadinene & 0.56 & -0.56 & 0.54 & -0.52 & 0.50 & & \\
\hline$\delta$-Cadinene & 0.54 & -0.57 & 0.55 & -0.63 & 0.51 & & \\
\hline
\end{tabular}

vitamin A content of milk was intermediate between that of bulk milk mixtures in the Netherlands (Hulshof et al., 2006) and that of milk from herds (Lucas et al., 2006b). The highest vitamin A contents in milk from grazing (Martin et al., 2004; Lucas et al., 2006a) were not found in our study. In farm cheese producers, Lucas et al. (2006a) observed that when the inputs of the basic ration are limiting, vitamin supplementation influences vitamin A content of milk. Thus, in our study, the effects of the nature of the basic ration could have been masked by the use of vitamin supplements whose nature and dose we do not know.

The 2 principal carotenoids identified in the bulk milk mixtures were $\beta$-carotene and lutein, $\beta$-carotene being largely in the majority. The $\beta$-carotene contents of our milk samples were equivalent to those of bulk milk mixtures in the Netherlands (Hulshof et al., 2006) and slightly lower than those of whole milk marketed in South African supermarkets (Smit et al., 2000), but their variability was higher, probably because of the stronger heterogeneity of our production conditions. Compared with milk from individual herds of Lucas et al. (2006b), the mean content measured in our study was $40 \%$ higher, and because our milk comes from the mixture of milk from 10 to 36 herds, the variability should be lower. The vitamin $\mathrm{E}$ contents were comparable to those measured in herd milk samples and were less variable (Lucas et al., 2006a).

As was observed for decades (Krukovsky et al., 1950) and recently confirmed (Martin et al., 2004; Lucas et al., 2006a), the variability in milk contents in carotenoids and vitamin $\mathrm{E}$ in this study was linked to the sampling period (i.e., the presence of grazed grass in the ration). Indeed, the level of $\beta$-carotene and vitamin $\mathrm{E}$ in milk is highly dependent on their respective level in the diet. Corn is $\beta$-carotene and vitamin $\mathrm{E}$ meager, and grass contains more $\beta$-carotene and vitamin $\mathrm{E}$ when it is fresh or ensiled than when it is dried, because these compounds decrease during drying and preservation proportionally to the degree of light exposure. Thus, the link between the proportion of grazed and ensiled grass with carotenoids and vitamin E in milk explains what was observed in this study. Moreover, during the winter feeding period, the effect of grass conservation method (silage vs. hay) on the vitamin $\mathrm{E}$ and $\beta$-carotene contents noted by Martin et al. (2004) was confirmed by the positive link between these compounds and the proportion of grass silage in the winter diets. During grazing, the absence of a link between the proportion of grass in the ration and the $\beta$-carotene and vitamin $\mathrm{E}$ content of milk suggest that with variable quantities of grass in the ration, the inputs of $\beta$-carotene and vitamin $\mathrm{E}$ are sufficient to allow a maximum secretion into the milk. This saturation phenomenon was recently observed for $\beta$-carotene by F. Calderon et al. (INRA, France; unpublished data) in an experiment in which various quantities of carotenoids were administered to dairy cows. Indeed, the absorption of vitamin E by secretory cells can be limited in the event of excess by saturation of the membrane receptor (Reboul et al., 

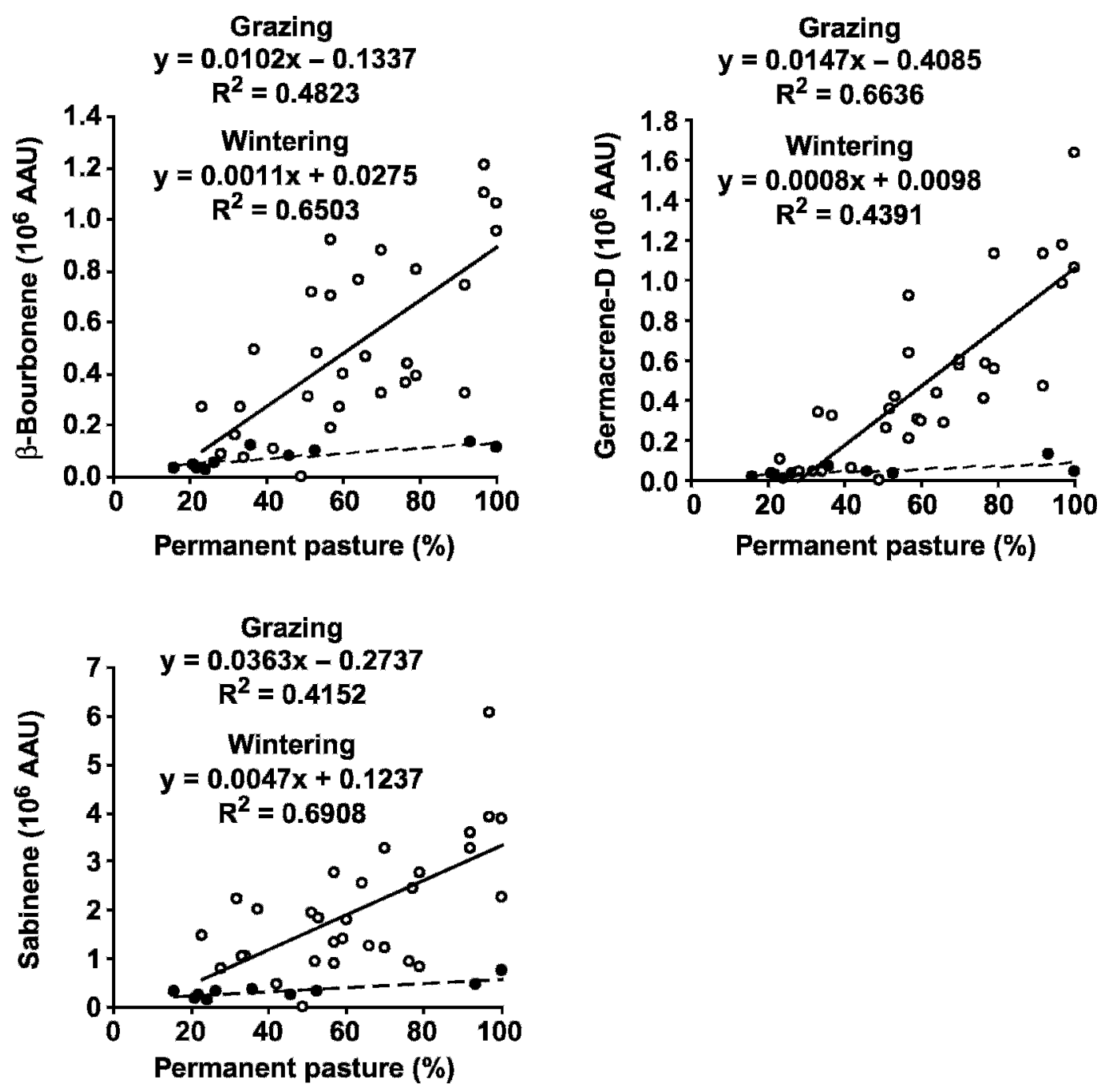

Figure 5. Relationships between the proportion of permanent pasture in the forage diet and terpenes (AAU = arbitrary area unit) in bulk milk samples from farms of 3 zones of the department of the Haute-Loire (Massif Central, France) during different times of the year. Wintering: ๑; grazing: $\bigcirc$; tendency for grazing: ——; tendency for wintering: - - - -.

2006). This phenomenon is more surprising for $\beta$-carotene, whose absorption is generally considered passive and not limiting (Sauvant et al., 2002).

The variability of the color traits of milk was comparable to that measured in experimental conditions on milk from animals receiving highly contrasted rations (rich in concentrate or corn silage vs. pasture; Martin et al., 2005; Nozière et al., 2006). Under the conditions of our study, in which color measurements were carried out from 2 to $3 \mathrm{~d}$ after milking, the link between the $\beta$-carotene content of milk and the yellow and color indices were comparable to those obtained in shortterm tests when the color was measured immediately after milking (Nozière et al., 2006). Logically, the principal production factors explaining the carotene content of milk also explain the color traits of milks.

\section{Terpenoids}

A great diversity of terpene molecules was found, similar to other papers on dairy products obtained at pasture (Viallon et al., 1999; Tornambé et al., 2006). Monoterpenoids outnumbered sesquiterpenoids in dairy products (Cornu et al., 2005). The most abundant terpenoids, such as $\alpha$-pinene, $\beta$-pinene, limonene, $\beta$ caryophyllene, and $\alpha$-copaene, have been found in milk volatile compounds and are considered common in other studies (Viallon et al., 1999; Fernandez et al., 2003). Most of the other terpenoid compounds, present only in trace amounts, have been reported in milk or cheeses (Fernandez et al., 2003). The majority of these compounds were identified in the milks from the 3 zones and the 4 periods tested but in extremely variable quan- 
tities, as was observed in other studies (Tornambé et al., 2006).

As observed by Cornu et al. (2002) and contrary to the results of Fernandez et al. (2003), some monoterpenoids and the majority of sesquiterpenoids were higher in the milk collected during the grazing period, especially in June and July, than in winter. These compounds come almost exclusively from the ingested plants, so this trend is linked to losses both during harvesting and forage storage (Cornu et al., 2002) and to differences in the botanical composition of the meadows used for hay and for grazing. During the grazing period, the low values observed in September were due to the intake by the cows of vegetative regrowth grass, called terpene poor (Tornambé et al., 2006). In addition, in September, the diets contained more concentrate and preserved forages and less grazed grass.

The higher terpene content of Z3 milk was due to the quasiexclusive use of permanent grassland in this zone. Indeed, most terpenoids were positively correlated to the proportion of permanent grassland in the ration. These results are in accordance with many showing that these compounds occur in greater amounts in milk of cows fed on diversified upland grassland than in those from cows fed on less broadly diversified or monospecific meadows (Bugaud et al., 2001). Indeed, terpenes abound in certain species, particularly dicotyledons such as Apiaceae, Lamiaceae, or Asteraceae families, whereas they are very low in most grasses, in corn, and leguminous plants (Mariaca et al., 1997; Cornu et al., 2001). During the winter period, in spite of the low number of measurements, links between a small number of the milk terpenes and the proportion of permanent grassland in the ration were observed, but the influence is reduced (definitely lower regression slope). In our study, the links between terpenoids and the variables describing the characteristics of the herds (breed, stage of lactation) are probably of indirect nature. Indeed, these factors were not known to modify milk terpenes. Moreover, the proportion of permanent grassland represented a total differentiation of the production systems with an association between the use of corn silage and the proportion of milk produced by Holstein animals and between the use of grass from permanent grassland and the proportion of milk produced by Montbéliarde cows. The negative links between terpenoids and the proportions of corn and temporary grassland or the quantities of concentrates express an opposition between these variables and the proportion of permanent grassland in the diet.

\section{CONCLUSIONS}

In this study, the variability in the composition of bulk milk mixtures was observed. The significant vari- ability was linked to the herd feed. Thus, it is possible for dairies to sell milk that differs in specific composition. The selection of tanker milk obtained during the grazing period allows the vitamin E, carotenoids, and yellow coloration of dairy products to increase as soon as the grazed grass represented half of the forages. It is necessary to consider both the high proportion of permanent grassland in regional zones and the period (grazed grass from the first growth cycle) to increase the terpene content of the milk.

\section{ACKNOWLEDGMENTS}

This work was funded by the Fonds Européen d'Orientation et de Garantie Agricole and Conseil Général de Haute-Loire. We acknowledge the Chambre d'Agriculture and Syndicat de Contrôle Laitier de la HauteLoire, the dairy industries and farmers involved in this study, J. C. Bonnefoy for milk collection and sampling, P. Capitan for laboratory analyses, and J. Curtis Williams for English rereading.

\section{REFERENCES}

AFNOR. 2003. Microbiology of food and animal feeding stuffs. Horizontal method for the enumeration of microorganisms. Colonycount technique at $30^{\circ} \mathrm{C}$. Standard NF EN ISO 4833.

Agabriel, C., C. Sibra, C. Journal, and J. B. Coulon. 2005. Interest and data analysis of survey in livestock farming: Reflection over 15 years of practice. Renc. Rech. Rumin. 12:331-334.

Bendall, J. G. 2001. Aroma compounds of fresh milk from New Zealand cows fed different diets. J. Agric. Food Chem. 49:4825-4832.

Bugaud, C., S. Buchin, J. B. Coulon, A. Hauwuy, and D. Dupont. 2001. Influence of the nature of alpine pastures on plasmin activity, fatty acid and volatile compound composition of milk. Lait 81:401-414.

CNERNA. 1986. Recommandations pour l'estimation de la contamination du lait en spores de Clostridia par la méthode de culture en milieu liquide. Rev. Lait Fr. 451:39-45.

Cornu, A., A. P. Carnat, B. Martin, J. B. Coulon, J. L. Lamaison, and J. L. Berdagué. 2001. Solid phase microextraction of volatile components from natural grassland plants. J. Agric. Food Chem. 49:203-209.

Cornu, A., N. Kondjoyan, B. Martin, I. Verdier-Metz, P. Pradel, J. L. Berdagué, and J. B. Coulon. 2005. Terpene profiles in Cantal and Saint-Nectaire-type cheese made from raw or pasteurised milk. J. Sci. Food Agric. 85:2040-2046.

Cornu, A., B. Martin, I. Verdier-Metz, P. Pradel, J. B. Coulon, and J. L. Berdagué. 2002. Use of terpene profiles in dairy produce to trace the diet of dairy cows. Grassland Sci. Eur. 7:550-551.

Fernandez, C., C. Astier, E. Rock, J. B. Coulon, and J. L. Berdagué. 2003. Characterization of milk by analysis of its terpene fractions. Int. J. Food Sci. Technol. 38:445-451.

Hulshof, P. J. M., T. van Roeckel-Jansen, P. van de Bovenkamp, and C. E. West. 2006. Variation in retinol and carotenoid content of milk and milk products in the Netherlands. J. Food Comp. Anal. 19:67-75.

Krukovsky, V. N., F. Whiting, and J. K. Loosli. 1950. Tocopherol, carotenoid and vitamin A content of milk fat and the resistance of milk to the development of oxidized flavors as influenced by breed and season. J. Dairy Sci. 33:791-796.

Lucas, A., C. Agabriel, B. Martin, A. Ferlay, I. Verdier-Metz, J. B. Coulon, and E. Rock. 2006a. Relationships between the conditions 
of cow's milk production and the contents of components of nutritional interest in raw milk farmhouse cheese. Lait 86:177-202.

Lucas, A., E. Rock, J. F. Chamba, I. Verdier-Metz, P. Brachet, and J. B. Coulon. 2006b. Respective effects of milk composition and cheese-making process on the cheese compositional variability in components of nutritional interest. Lait 86:21-41.

Mariaca, R. G., T. F. H. Berger, R. Gauch, M. I. Imhof, B. Jeangros, and J. O. Bosset. 1997. Occurrence of volatile mono- and sesquiterpenoids in highland and lowland plant species as possible precursors for flavour compounds in milk and dairy products. J. Agric. Food Chem. 45:4423-4434.

Martin, B., V. Fedele, A. Ferlay, P. Grolier, E. Rock, D. Gruffat, and Y. Chilliard. 2004. Effects of grass-based diets on the content of micronutrients and fatty acids in bovine and caprine dairy products. Grassland Sci. Eur. 9:876-886.

Martin, B., I. Verdier-Metz, S. Buchin, C. Hurtaud, and J. B. Coulon. 2005 . How do the nature of forages and pasture diversity influence the sensory quality of dairy livestock products? Anim. Sci. 81:205-212.

Moio, L., L. Rillo, A. Ledda, and F. Addeo. 1996. Odorous constituents of ovine milk in relationship to diet. J. Dairy Sci. 79:1322-1331.
Nozière, P., B. Graulet, A. Lucas, B. Martin, P. Grolier, and M. Doreau. 2006. Carotenoids in ruminants: From forages to dairy products. Anim. Feed Sci. Technol. 131:418-450.

Reboul, E., A. Klein, F. Bietrix, B. Gleize, C. Malezet-Desmoulins, M. Schneider, A. Margotat, L. Lagrost, X. Collet, and P. Borel. 2006. Scavenger receptor class B type I (SR-BI) is involved in vitamin $\mathrm{E}$ transport across the enterocyte. J. Biol. Chem. 281:4739-4747.

Sauvant, P., P. Grolier, and V. Azais-Braesco. 2002. Vitamin A, Nutritional significance. Pages 2657-2664 in Encyclopaedia of Dairy Science. H. Roginsky, J. W. Fuquay, and P. F. Fox, ed. Acad. Press, London, UK.

Smit, L. E., H. C. Schönfeldt, W. H. J. de Beer, and M. F. Smith. 2000 . The effect of locality and season on the composition of South African whole milk. J. Food Compost. Anal. 13:245-267.

Tornambé, G., A. Cornu, P. Pradel, N. Kondjoyan, A. P. Carnat, M. Petit, and B. Martin. 2006. Changes in terpene content in milk from pasture-fed cows. J. Dairy Sci. 89:2309-2319.

Viallon, C., B. Martin, I. Verdier-Metz, P. Pradel, J. P. Garel, J. B. Coulon, and J. L. Berdagué. 2000. Transfer of monoterpenes and sesquiterpenes from forages into milk fat. Lait 80:635-641.

Viallon, C., I. Verdier-Metz, C. Denoyer, P. Pradel, J. B. Coulon, and J. L. Berdagué. 1999. Desorbed terpenes and sesquiterpenes from forages and cheeses. J. Dairy Res. 66:319-326. 